\title{
HUBUNGAN OBESITAS DAN AKTIVITAS FISIK DENGAN KEJADIAN DIABETES MELLITUS TIPE 2 DI PUSKESMAS WONOGIRI 1
}

\author{
Nine Elissa Maharani ${ }^{(1)}$, Suryono1 ${ }^{(2)}$, Bagus Fandy Ardiyanto $2^{2}$ \\ ${ }^{1}$ Dosen Fakultas Kesehatan Masyarakat Univet Bantara Sukoharjo \\ ${ }^{2}$ Dosen Fakultas Kesehatan Masyarakat Univet Bantara Sukoharjo \\ ${ }^{3}$ Mahasiswa Fakultas Kesehatan Masyarakat Univet Bantara Sukoharjo \\ elissapanjimomo@gmail.com
}

\begin{abstract}
ABSTRAK
Prevalensi diabetes mellitus tipe 2 di puskesmas Wonogiri 1 dalam dua tahun terakhir dari tahun 2014 sampai 2015 meningkat yaitu tahun 2014 sebanyak 269 orang dan tahun 2015 meningkat menjadi 278. Tujuan penelitian ini adalah untuk mengetahui hubungan obesitas dan aktivitas fisik dengan kejadian diabetes mellitus tipe 2 di Puskesmas Wonogiri 1. Jenis penelitian ini adalah survey analitik dengan pendekatan kasus kontrol. Populasi dalam penelitian ini semua pasien diabetes mellitus tipe 2 di Puskesmas Wonogiri 1 yang berobat dari bulan Januari sampai Mei 2016 sebanyak 236 pasien. Sampel dalam penelitian ini sebanyak 42 orang yag terdiri dari 21 sampel kasus diabetes mellitus tipe 2 dan 21 sampel kontrol yang bukan penderita diabetes mellitus tetapi memiliki karakteristik yang sama. Teknik pengambilan sampel menggunakan si mpel random sampling. Variabel bebas adalah obesitas dan aktivitas fisik. Variabel terikat kejadian diabetes mellitus tipe 2. Analisis data menggunakan chi square dengan $\alpha 5 \%$ dan OR. Hasil penelitian ini menunjukkan tidak ada hubungan obesitas $(\mathrm{p}=0.001 ; \mathrm{OR}=12,000)$ dan aktivitas fisik $(\mathrm{p}=0.015$; $\mathrm{OR}=0.200)$ dengan kejadian diabetes mellitus tipe 2 di Puskesmas Wonogiri 1. Disarankan pihak puskesmas melakukan sosialisasi tentang faktor-faktor penyebab diabetes mellitus, gejala, komplikasi dan usaha mencegah diabetes mellitus.
\end{abstract}

Kata kunci: obesitas, aktifitas fisik, diabetes mellitus tipe II

\begin{abstract}
The prevalence of type 2 diabetes in Puskesmas Wonogiri I in the last two years from 2014 to 2015 it is known that a new visit patients with diabetes in 2014 as many as 269 people and in 2015 increased to 278 . This study aims to determine the relationship of obesity and physical activity with the incidence of Type 2 Diabetes Mellitus in Puskesmas Wonogiri I. This research is analytic survey research using case control study design. The population in this study were all patients with type 2 diabetes in Puskesmas Wonogiri I from January to May 2016 as many as 236 patients. The sample in this study as many as 42 people consisting of 21 samples taken from cases of patients suffering from diabetes and 21 control samples taken from patients who did not have diabetes but have the same characteristics. Mechanical Sampling using simple random sampling technique. The independent variables in this study is that obesity and physical activity (sports), while the dependent variable in this study was the incidence of Type 2 Diabetes Mellitus Data were analyzed using chi square $\alpha=0.05$ and Odd Ratio (OR). The results showed no relationship between obesity $(\mathrm{p}=0.001 ; \mathrm{OR}=12,000)$, and physical activity $(\mathrm{p}=0.015$; $\mathrm{OR}=0.200)$ in the incidence of Type 2 Diabetes Mellitus in Puskesmas Wonogiri Wonogiri I. I suggested to the health center to better socialize factor Factors causing diabetes mellitus, symptoms of diabetes mellitus, complications of diabetes mellitus, and how to prevent diabetes mellitus.
\end{abstract}

Keywords: Obesity, physical activity, Diabetes mellitus type 2 


\section{PENDAHULUAN}

Diabetes Melitus (DM) atau kencing manis adalah kelainan metabolis yang disebabkan oleh berbagai faktor, dengan gejala-gejala berupa hiperglikemia (peningkatan kadar glukosa darah) kronis dan gangguan metabolisme pada karbohidrat, lemak, dan protein. Diabetes Melitus diklasifikasikan menjadi DM tipe 1, yang dikenal sebagai insulin-dependent atau childhood onset diabetes, ditandai dengan kurangnya produksi insulin dan DM tipe 2, yang dikenal dengan non-insulin-dependent atau adult-onset diabetes, disebabkan ketidakmampuan tubuh menggunakan insulin secara efektif yang kemudian mengakibatkan kelebihan berat badan dan kurang aktivitas fisik. Dari data yang diperoleh dari Dinas Kesehatan Kabupaten Wonogiri pada tahun 2015 diperoleh data kasus Diabetes Melitus sebanyak 2143 kasus dan 1954 kasus diantaranya adalah Diabetes Melitus tipe 2. Di Kabupaten Wonogiri Penyakit Diabetes Melitus menduduki peringkat kedua setelah hipertensi Penyakit Tidak Menular. Data prevalensi DM tipe 2 di Puskesmas Wonogiri I pada dua tahun terakhir yaitu 2014-2015 diketahui bahwa kunjungan baru pasien DM tahun 2014 sebanyak 269 orang dan tahun 2015 meningkat menjadi 278, dengan sebagian besar diantaranya berumur 60-69 tahun. Peneliti tertarik mengambil tempat di Puskesmas Wonogiri I dikarenakan mempertimbangkan jumlah kasus terbesar dan yang menempati likup perkotaan serta jumlah kasus yang meningkat dari tahun 2014-2015.

Berdasarkan uraian di atas, maka peneliti tertarik untuk melakukan penelitian tentang Hubungan Obesitas dan Aktivitas fisik (Olahraga) dengan Kejadian Diabetes Melitus Tipe 2 di Puskesmas Wonogiri I.

\section{METODE}

\section{Populasi dan Sampel}

Dalam penelitian ini peneliti membedakan populasi menjadi 2 yaitu populasi kasus dan populasi kontrol. Populasi kasus adalah semua kasus Diabetes Melitus tipe 2 di
Puskesmas wonogiri I dari bulan Januari sampai Mei 2016 yaitu sebanyak 236 pasien. Populasi Kontrol adalah semua pasien yang tidak didiagnosa sebagai penderita Diabetes Melitus tipe 2 dan mempunyai karakteristik yang sama dengan penderita Diabetes Melitus tipe 2 di Puskesmas Wonogiri I. Berdasarkan perhitungan sampel tersebut, maka jumlah sampel kasus dalam penelitian ini adalah 21 orang. Dengan perbandingan antara sampel kasus dan sampel kontrol sebesar 1:1, maka jumlah sampel kontrol dalam penelitian ini adalah 21 orang.

Sampel kasus pada penelitian ini adalah 21 pasien yang mengidap Diabetes Melitus tipe 2 di Puskesmas Wonogiri I dengan perbandingan sampel kasus dan sampel kontrol sebesar 1:1.

Sampel kontrol dalam penelitian ini adalah pasien yang tidak mengidap diabetes melitus tipe 2 di puskesmas Wonogiri I dengan perbandingan sampel kasus dan sampel kontrol sebesar 1:1. Pengambilan sampel kontrol dilakukan dengan matching untuk mengendalikan variabel pengganggu.

\section{Teknik Pengumpulan Data}

Dalam penelitian ini, teknik yang digunakan peneliti dalam mengumpulkan data adalah sebagai berikut:

1. Teknik pengumpulan data primer Pengambilan data primer pada penelitian ini dilakukan dengan observasi dan wawancara kepada responden untuk mengisi kuesioner.

2. Data sekunder dalam penelitian ini berasal dari Puskesmas Wonogiri I. Berupa data jumlah kejadian Diabetes Melitus tipe 2 dan profil Puskesmas Wonogiri I Kabupaten Wonogiri dari bulan januari sampai mei 2016.

\section{Teknik Analisis Data}

Teknik analisis data dalam penelitian ini meliputi analisis univariat untuk menggambarkan tiap-tiap variabel yang diteliti dan analisis bivariat menggunakan uji statistik Chi Square dengan $\alpha 5 \%$ untuk mengetahui ada tidaknya hubungan antara variabel bebas dengan variabel terikat (Riyanto, 2011). 


\section{HASIL}

Analisis Univariat

Kejadian Obesitas

Distribusi hasil penelitian mengenai Obesitas pada pasien di Wilayah Kerja Puskesmas Wonogiri I, sebagai berikut:

Tabel 1. Distribusi frekuensi Obesitas pada Pasien di Wilayah Kerja Puskesmas Wonogiri I

\begin{tabular}{llll}
\hline No & Keterangan & F & \% \\
\hline 1 & Obesitas & 20 & 47,6 \\
2 & Tidak Obesitas & 22 & 52,4 \\
\hline & Jumlah & 42 & 100 \\
\hline
\end{tabular}

Berdasarkan tabel 1 distribusi frekuensi dapat Puskesmas Wonogiri I sebagian besar tidak diketahui bahwa pasien di Wilayah Kerja obesitas yaitu sebanyak 22 orang $(52,4 \%)$.

\section{Aktivitas fisik}

Distribusi hasil penelitian mengenai aktivitas fisik pada pasien di Wilayah Kerja Puskesmas Wonogiri I, sebagai berikut:

Tabel 2. Distribusi Frekuensi Aktivitas fisik pada Pasien di Wilayah Kerja Puskesmas Wonogiri I

\begin{tabular}{llll}
\hline No & Aktivitas fisik & F & \% \\
\hline 1 & Baik & 19 & 45,2 \\
2 & Buruk & 23 & 54,8 \\
\hline & Jumlah & 42 & 100 \\
\hline
\end{tabular}

Dari tabel 2 distribusi frekuensi dapat aktivitas fisik buruk yaitu sebanyak 23 orang diketahui bahwa pasien di Wilayah Kerja (54,8\%).

Puskesmas Wonogiri I sebagian besar memiliki

\section{Analisis Bivariat}

Hubungan Obesitas dengan Kejadian DM Tipe 2
Berdasarkan hasil uji chi-square dari data penelitian tentang obesitas pasien di Wilayah Kerja Puskesmas Wonogiri I, didapatkan hasil sebagai berikut:

Tabel 3. Hubungan Obesitas dengan Kejadian DM Tipe 2 di Wilayah Kerja Puskesmas Wonogiri I Kejadian Diabetes Melitus Tipe 2

\begin{tabular}{|c|c|c|c|c|c|c|c|c|c|}
\hline \multirow{3}{*}{ Obesitas } & \multicolumn{4}{|c|}{ DM Tipe 2} & \multirow{2}{*}{\multicolumn{2}{|c|}{ Total }} & \multirow{3}{*}{$\begin{array}{l}\text { Nilai } \\
P_{\text {value }}\end{array}$} & \multirow{3}{*}{$\begin{array}{l}\text { Nilai } \\
\text { OR }\end{array}$} & \multirow{3}{*}{$\begin{array}{l}\text { Nilai } \\
\text { CI }\end{array}$} \\
\hline & \multicolumn{2}{|c|}{ Kasus } & \multicolumn{2}{|c|}{ Kontrol } & & & & & \\
\hline & $\mathrm{f}$ & $\%$ & $\mathrm{~F}$ & $\%$ & $\mathrm{~F}$ & $\%$ & & & \\
\hline Tidak Obesitas & 6 & 28,6 & 16 & 76,2 & 22 & 52,4 & & & $2,012-$ \\
\hline Obesitas & 15 & 71,4 & 5 & 23,8 & 20 & 47,6 & 0,002 & 8,000 & 31,803 \\
\hline Jumlah & 21 & 100 & 21 & 100 & 42 & 100 & & & \\
\hline
\end{tabular}

Berdasarkan tabel 3 diketahui bahwa kelompok kasus yang memiliki obesitas sebanyak 15 orang $(71,4 \%)$ dan kelompok kontrol yang tidak obesitas sebanyak 16 orang $(76,2 \%)$. Hasil uji chi-square diperoleh nilai $p(0,002)<$ $(0,05)$. Dengan demikian Ho ditolak, yang berarti ada hubungan yang bermakna antara

Hubungan Aktivitas fisik dengan DM Tipe 2 Berdasarkan hasil uji chi-square dari data penelitian tentang aktivitas fisik pasien di

Tabel 4. Hubungan Aktivitas fisik dengan Kejadian DM Tipe 2 di Wilayah Kerja Puskesmas Wonogiri I

\begin{tabular}{llllll}
\hline Aktivitas fisik & DM Tipe 2 & Total & Nilai & Nilai & Nilai \\
\hline
\end{tabular}

obesitas dengan kejadian DM Tipe 2. Perhitungan risk estimate didapatkan nilai OR $=8,000>1$ dengan $95 \% \mathrm{CI}=2,012-31,803$ menunjukkan bahwa risiko untuk DM Tipe 2 pada pasien yang memiliki obesitas adalah 8,000 kali lebih besar dibandingkan yang tidak memiliki obesitas.

Wilayah Kerja Puskesmas Wonogiri I, didapatkan hasil sebagai berikut: 


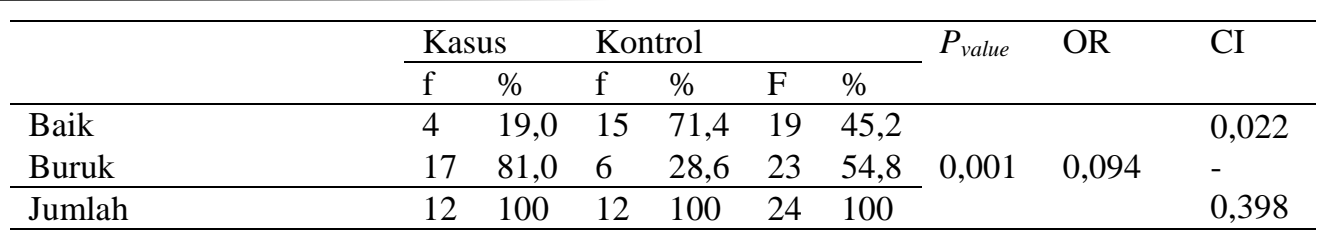

Berdasarkan tabel 4 diketahui bahwa kelompok kasus yang memiliki aktivitas fisik buruk sebanyak 17 orang $(81,0 \%)$ dan kelompok kontrol yang memiliki aktivitas fisik baik sebanyak 15 orang $(71,4 \%)$. Hasil uji chisquare diperoleh nilai $p(0,001)<(0,05)$. Dengan demikian Ho ditolak, yang berarti ada

\section{PEMBAHASAN}

\section{Analisis Univariat}

\section{Kejadian Obesitas}

Sebagian besar pasien yang memiliki obesitas berjenis kelamin perempuan hal ini disebabkan kurangnya aktivitas fisik yang berat karena mayoritas pasien memiliki pekerjaan sebagai Ibu Rumah Tangga (IRT) dan telah berusia lanjut. Menurut Susilo (2011) hal itu disebabkan karena metabolisme perempuan lebih lambat daripada laki-laki karena laki-laki $10 \%$ lebih tinggi dibanding perempuan, dan perempuan memiliki lebih sedikit otot dibandingkan laki-laki karena otot membakar lemak lebih banyak dari sel-sel lain. Menurut Penelitian Unjani (2015) menunjukan bahwa penderita obesitas terbanyak berasal dari kelompok dengan usia lanjut, ini menggambarkan semakin bertambahnya usia akan berisiko mengalami obesitas, karena terjadinya akumulasi lemak secara berlebihan di dalam tubuh yang didukung perubahan pola makan.

\section{Aktivitas fisik}

Sebagian besar pasien jarang melakukan aktivitas fisik yang dapat mengeluarkan keringat dan olahraga karena banyak yang sudah berusia lanjut, yaitu 60-69 th. Hal ini sesuai penelitian Nurhidayah (2016) menunjukan bahwa orang yang berusia lanjut lebih banyak bergantung pada orang lain dan cenderung melakukan aktivitas pasif seperti duduk santai sambil berbincang, mengikuti kegiatan masyarakat dan beraktivitas ringan. Aktivitas yang paling sering dilakukan saat mempunyai waktu luang adalah duduk santai. Aktivitas fisik buruk juga sebagian besar dialami pasien yang berjenis kelamin perempuan dan memiliki pekerjaan IRT. Menurut Susilo (2011) hal itu disebabkan karena metabolisme perempuan lebih lambat daripada laki-laki karena laki-laki $10 \%$ lebih hubungan yang bermakna antara aktivitas fisik dengan DM Tipe 2. Perhitungan risk estimate didapatkan nilai $\mathrm{OR}=0,094<1$ dengan $95 \%$ $\mathrm{CI}=0,022-0,398$ menunjukkan bahwa aktivitas fisik baik merupakan faktor protektif atau dapat mengurangi risiko terjadinya DM tipe 2.

tinggi dibanding perempuan, dan perempuan memiliki lebih sedikit otot dibandingkan lakilaki karena otot membakar lemak lebih banyak dari sel-sel lain.

Analisis Bivariat

\section{Hubungan antara Obesitas dengan kejadian DM Tipe 2 di Puskesmas Wonogiri I}

Kejadian obesitas sebagian besar dialami oleh pasien yang berumur 60-69 tahun sebanyak 14 orang $(33,3 \%)$, hal itu disebabkan karena menurunnya aktivitas seseorang seiring bertambahnya usia sehingga pembakaran kalori berkurang dan pada akhirnya lemak tertimbun dalam tubuh dan menyebabkan obesitas. Sedangkan jenis kelamin perempuan sebanyak 14 orang (33,3\%), menurut Susilo (2011) hal itu disebabkan karena metabolisme perempuan lebih lambat daripada laki-laki karena laki-laki $10 \%$ lebih tinggi dibanding perempuan, dan perempuan memiliki lebih sedikit otot dibandingkan laki-laki karena otot membakar lemak lebih banyak dari sel-sel lain. Sebagian memiliki pekerjaan IRT sebanyak 9 orang $(21,4 \%)$. Penelitian ini sebanding dengan penelitian yang dilakukan oleh Ari Fatmawati (2010) menyatakan bahwa terdapat 39 orang $(52,7 \%)$ dari 74 pasien yang memiliki obesitas mengidap DM Tipe 2. Selain itu, terdapat hubungan yang bermakna antara obesitas dengan DM Tipe 2 (p value sebesar 0,003). Penelitian lain yang dilakukan oleh Shara Kurnia Trisnawati dan Soedijono Setyorogo (2013) bahwa sebanyak 26 orang $(76,5 \%)$ dari 31 pasien memiliki obesitas dan menderita DM Tipe 2 serta terdapat hubungan yang bermakna antara obesitas dengan DM Tipe 2 (p value = 0,006). Hasil penelitian ini sesuai dengan teori yang dikemukakan oleh Tandra (2008) yang menyatakan bahwa lebih dari 8 diantara penderita DM tipe 2 adalah mereka yang mengalami kegemukan. Makin banyak jaringan 
lemak, jaringan tubuh dan otot akan semakin resisten terhadap kerja insulin (insulin resistance), terutama bila lemak tubuh atau kelebihan berat badan terkumpul di daerah sentral atau perut (central obesity). Lemak ini akan memblokir kerja insulin sehingga glukosa tidak dapat diangkut ke dalam sel dan menumpuk dalam peredaran darah. Tubuh yang cenderung gemuk lebih banyak menyimpan lemak tubuh dan lemak tidak terbakar, terjadi kekurangan hormon insulin untuk pembakaran karbohidrat, sehingga lebih berpeluang besar terjadinya DM tipe 2 .

\section{Hubungan antara Aktivitas fisik dengan}

DM Tipe 2 di Puskesmas Wonogiri I

Berdasarkan hasil penelitian menunjukkan bahwa kategori pasien terbanyak memiliki aktivitas fisik buruk, yaitu pasien yang jarang melakukan olahraga sebanyak 23 orang $(54,8 \%)$. Aktivitas fisik yang buruk sebagian besar dialami pasien yang berumur 60-69 tahun karena kurangnya aktivitas fisik yang dapat mengeluarkan keringat dan olahraga yang disebabkan faktor usia yang menyebabkan penurunan fungsi fisik sebanyak 12 orang $(28,6 \%)$. Berjenis kelamin perempuan sebanyak 18 orang $(42,9 \%)$ itu disebabkan karena metabolisme perempuan lebih lambat daripada laki-laki, dan memiliki pekerjaan IRT sebanyak 13 orang (31\%) yang jarang melakukan aktivitas fisik yang dapat mengeluarkan keringat disebabkan pekerjaan rumah tangga yang banyak. Penelitian ini sebanding dengan penelitian yang dilakukan oleh Arif Fatmawati (2010) menyatakan bahwa 43 orang $(58,1 \%)$ dari 74 pasien memiliki aktivitas fisik buruk dan menderita DM Tipe 2 . Selain itu, terdapat hubungan yang bermakna antara obesitas dengan DM Tipe 2 dari hasil hitung chi-square diperoleh ( $\mathrm{p}$ value sebesar 0,005 ). Penelitian lain yang dilakukan oleh Shara Kurnia Trisnawati dan Soedijono Setyorogo (2013) bahwa sebanyak 22 orang $(75,9 \%)$ dari 31 pasien memiliki aktivitas fisik ringan dan menderita DM Tipe 2 serta terdapat hubungan yang bermakna antara aktivitas dengan DM Tipe 2 ( $\mathrm{p}$ value $=0,038$ ). Hasil penelitian ini sesuai dengan teori yang dikemukakan oleh Tandra (2008) yang menyatakan bahwa semakin kurang gerak badan, semakin mudah seseorang terkena diabetes melitus. Olahraga atau aktivitas fisik membantu kita untuk mengontrol berat badan. Glukosa darah dibakar menjadi energi, dan selsel tubuh menjadi lebih sensitif terhadap insulin. Peredaran darah menjadi lebih baik, dan risiko terjadinya diabetes melitus tipe 2 akan turun sampai 50 persen.

\section{SIMPULAN}

Berdasarkan hasil penelitian dapat disimpulkan bahwa:

1. Karakteristik pasien kasus 16 orang perempuan $(76,2 \%)$, pekerjaan IRT 11 orang $(52,4 \%)$, dan Umur 60-69 tahun 13 orang $(61,9 \%)$. Sedangkan karakteristik pasien kontrol 16 orang perempuan (76,2\%), pekerjaan IRT 13 orang $(61,9 \%)$, dan umur 60-69 tahun 13 orang $(61,9 \%)$.

2. Dari 42 pasien yang diambil dari pasien Puskesmas Wonogiri I, 20 orang mengalami obesitas $(47,6 \%)$ dan 22 orang tidak mengalami obesitas $(52,4 \%)$.

3. Dari 42 pasien yang diambil dari pasien Puskesmas Wonogiri I, 23 orang memiliki aktivitas fisik yang buruk $(54,8 \%)$ dan 19 orang memiliki aktivitas fisik yang baik $(45,2 \%)$.

4. Ada hubungan yang bermakna antara obesitas dengan kejadian Diabetes Melitus Tipe 2 di Puskesmas Wonogiri I Kabupaten Wonogiri dan obesitas menjadi faktor risiko yang berarti orang yang menderita obesitas 8 kali lebih rentan terserang DM tipe $2(p=$ $0,002<0,05$ dengan $\mathrm{OR}=8,000$ ).

5. Ada hubungan yang bermakna antara aktivitas fisik dengan kejadian Diabetes Melitus Tipe 2 di Puskesmas Wonogiri I Kabupaten Wonogiri dan aktivitas fisik menjadi faktor protektif untuk DM tipe 2 yang berarti orang yang memiliki aktivitas fisik baik 0,094 kali dapat terhindar DM tipe $2(p=0,001<0,05$ dengan $\mathrm{OR}=$ 0,094).

\section{DAFTAR PUSTAKA}

Almatsier S. 2009. Prinsip Dasar Ilmu gizi. Jakarta: Gramedia Pustaka Utama

Fatmawati, Ari. 2010. Faktor Risiko Kejadian Diabetes Melitus Tipe 2 Pasien Rawat Jalan. Skripsi. Semarang: Universitas Negeri Semarang.

Riyanto, Agus. 2011. Aplikasi Metodologi Penelitian Kesehatan. Yogyakarta: Nuha Medika. 
Jurnal Manajemen Informasi dan Administrasi Kesehatan (J-MIAK)

Volume 01, No 01, Tahun 2018

ISSN: 2621-6612

Email:d3perinfokesunivet@gmail.com

Halaman: 40-48

Suiraoka I. 2012. Penyakit Degeneratif:

Mengenal, Mencegah, dan

Mengurangi Faktor Risiko 9

Penyakit Degeneratif. Yogyarta:

Nuha Medika.

Susilo, Yekti, Ari Wulandari. 2011. Cara Jitu

Mengatasi Kencing Manis.

Yogyakarta: Andi Yogyakarta

Tandra, Hans. 2008. Segala Sesuatu Yang

Harus Anda Ketahui Tentang

Diabetes. Jakarta : Gramedia. 